\title{
Supporting the career development of older employees: an HRD study in a Dutch company
}

\section{Bertien Rhebergen and Ida Wognum}

\begin{abstract}
Many organisations are confronted with an ageing workforce. Older employees are often seen as less flexible and open to HRD activities than their younger colleagues, yet rapid developments taking place within society and organisations require a flexible and responsive workforce. The necessary knowledge and skills demanded here can be taught through HRD activities. In 1995 a quantitative exploratory survey into the conditions considered important for the career development or mobility of older workers was carried out within a Dutch multinational chemical company. From a training and development viewpoint, these conditions are defined as demands made on corporate HRD policy, HRD activities and employees' willingness to learn, as well as stimulating factors that promote the career development of older workers. Results show that while the company operated an age-awareness personnel pol$i c y$, this still focused on younger employees so that participants in the career development process were insufficiently stimulated in their roles and traditional formal HRD activities had little effect on older workers' careers. This article describes the survey, highlighting its major results, and offers recommendations.
\end{abstract}

Many organisations are confronted with an ageing workforce. This may cause a problem in that older employees are often seen as less mobile and flexible and thus less able to deal with rapid changes occurring in organis-

$\square$ Bertien Rhebergen is a Training Consultant for SBK Advice and Training, Helmond, The Netherlands. Ida Wognum is Assistant Professor in the Department of Educational Administration, University of Twente, Faculty of Educational Science and Technology, The Netherlands. ations. The mobility of older employees is therefore a topical theme in personnel management[1]. One solution to this situation might be to increase specific educational provision for older employees, but research shows that most educational training is aimed at young 'high potentials' rather than older employees, the reason being the unfounded stereotyping of older employees: they are seen as inflexible and unmotivated towards change. Training therefore is often not considered an appropriate tool for updat- 
ing these workers' qualifications[2]. Moreover, employers see scant investment in educating older employees in terms of 'pay-off'. According to some authors, this may be the key reason for older people not functioning optimally[3].

One of the questions frequently asked in articles on mobility is how can human resource developers contribute positively to mobility problems[4]? This article addresses possible answers in response to older workers' careers from an HRD point of view.

Mobility is basically a career planning and -management question[5]. The growing interest in mobility has been created by at least four trends. One has been already touched upon: many organisations have to deal with an ageing work force and feel the need to develop policies that take this into account. This ageing workforce is largely caused by demographic tendencies. Moreover, the Dutch government no longer allows organisations to fire older workers in difficult times. Another trend is that organisations have become 'flatter'. In the past bigger always meant 'better' and growth in terms of personnel was a major goal of companies; nowadays there is a trend towards smaller, leaner and less hierarchical organisations[6]. As a result there are fewer possibilities for vertical career moves. A third trend is that work contracts are more flexible. Lifelong employment is becoming the exception for people of all ages: corporations have a core staff and during busy times people are hired on a temporary basis. It is thus important to keep in-company workers flexible and openminded so that they can easily be switched between jobs and organisations. A fourth trend is the responsibility of employees for their own career development. In the past employees were more or less 'passive' concerning their career when they entered an organisation. Employers were responsible for planning their careers and gave employees little control over their own progress, preferring to place and promote without consultation[7]. Under the current uncertain economic conditions this attitude no longer suffices. Employees are expected to plan their own careers. This is a new responsibility, especially for older employees.

Organisations, confronted with these trends, are looking for solutions. Given the fact that it is people who sell and market, develop and create products, make decisions and implement programmes, human resources are vital to an organisation's success[8]. Not having the right skilled people when they are needed can seriously undermine the success of strategic business choices.

One of the tools often mentioned in career management literature for keeping personnel updated and ready for change is training and development. However, this has been insufficiently translated into practical conditions and implications. For this reason, in 1995 a quantitative exploratory survey was undertaken within a large Dutch multinational, multisited chemical company, confronted with these trends. The primary purpose of this research was to gain a full picture of the problems and educational needs of ageing workers in order to optimise educational strategies and career policies.

The starting point for the research was: what conditions (perceived from a training and development perspective) support the career development of older employees?[9] This article describes the theoretical framework used, the research design, the major results and provides a conclusion and recommendations concerning the contributions HRD specialists could make regarding the careers of older workers.

\section{Theoretical framework}

An age-awareness approach is essential to meet the mobility needs of older workers. Here the authors define this as preventive policies aimed at keeping workers healthy and productive for as long as possible. The word 'preventive' is of special importance: if organisations take appropriate actions, from the outset of people's careers, reactive curative policies at an advanced age are superfluous. With an age-awareness personnel policy, human resources management and development activities apply to all employees regardless of age (though they make allowances for special needs at different age and career stages). The boundary between 'old' and 'young' is arbitrary because of the inconsistency of ages mentioned in literature. Because of the preventive nature of an age-awareness approach, and in accordance with the wishes of the company in this research, every employee 35 years and older was defined as an older worker.

Career development is a sub-discipline of age-awareness personnel management. The term 'career' is defined here as an individually perceived sequence of attitudes and 
behaviours towards work experiences and activities over the span of a person's working life[10]. Typically, the term connotes upward mobility and aspiration. From this perspective, career management is not thought of as being important for people who make horizontal career moves. Under the current flatter structures, however, a broader concept of defining a career seems to be a cause for discussion. Career development nowadays means development in both a vertical and horizontal direction[11]. Individual careers evolve from the skills and goals an individual brings to an organisation interacting with the work experiences and opportunities the organisation provides[12]. Effective human resource policies and practices must allow a continuous process of matching individual career needs with organisational requirements. This underlines the importance of personal career planning and management. Personal career planning is a process managed by the worker, and not the organisation. To do this, employees need insight into their own knowledge, skills, expectations and possibilities, while an organisation's role is to coach, advise and provide learning activities for self-inquiry. It is generally accepted that the more control individuals have over their career choices, the more likely they will choose a career path in keeping with their core competencies and values, thereby ensuring satisfaction and growth[13]. A major goal therefore is to plan careers which embody new tasks and learning activities and which, regardless of the career direction (vertical or horizontal), guarantee personal learning.

However, learning activities have to meet certain conditions to result in career development. A literature review was undertaken to find out what these might be. This revealed the importance of three groups of conditions: those related to policy, HRD-activities and the individual worker. Figure 1 shows an overview of the conditions found in relevant literature. While these do not guarantee career development, they should be seen as certainly facilitating it. They act as a theoretical basis for developing research instruments. In short, policy conditions imply that ageawareness personnel management starts with a clear awareness that the way older workers were treated in the past creates problems of flexibility within organisations[14]. Next, organisations need to provide material and non-material resources to improve this situation. Measures have to fit the strategic choices made[15]. Since human resources management within organisations is largely the linemanager's responsibility, they need to inspire older workers. Internal corporate career policy has to be communicated openly so that workers can anticipate requirements[16]. An additional but not necessary condition is an appropriate rewarding structure (both material and non-material), like recognising older workers' development.

HRD activities are broadly defined as including all structured learning activities like training and courses as well as learningon-the-job. A first precondition for HRD activities is the creating of an appropriate learning climate in which workers are challenged to learn continually[17]. Such a climate pays attention to the individual educational needs of employees because every individual is unique[18]. Next, employers should give employees an insight into the process of personal career planning[19]. The shift towards personal career management is only possible when workers have appropriate knowledge of this. The design and development of HRD activities should take into account age-awareness instructional principles like giving constructive feedback and providing a tailored social and logistic learning context[20]. Finally, line managers need to be (re)trained for their coaching and inspiring role.

Conditions at individual level relate to the learning attitude of older people[21]. A 'good' learning attitude is characterised by a willingness to learn, a healthy critical view on one's own possibilities, an entrepreneurial attitude towards one's career and the ability to view change as a 'chance' and not as a 'threat'.

\section{Research questions}

Most career management problems are dealt with from the expert or specialist perspective. Little research is done into gaining insight into workers' perceptions. Examining these perceptions will add to current career management theories. Daily education and career development practices in multinationals occur via stakeholders and participants in the career development process, so that their role also has to be examined. Thus, the central research question is:

\footnotetext{
How do older workers perceive the conditions for age-awareness career development and the role of the line-manager, employee and personnel management specialists in this process?
} 
Policy conditions

- awareness of older workers' problems

- providing resources

- strategic imbedded measures

- inspiring line-managers' role

- open communication

- appropriate rewarding resources
Conditions related to HRD activities

- creating an appropriate learning climate

- paying attention to individual learning needs

- paying attention to personal career planning

- an age-awareness instructional method

- paying attention to the (re)training of line managers in their coaching role
Conditions related to individual workers

- a learning attitude

- critical reflection/self assessment

- entrepreneurship towards own career

- creativity

Figure 1: An overview of conditions for age-aware career development

This question can be sub-divided into the following:

1. to what extent is the company's HRD policy perceived as directed at older employees;

2. to what extent do older workers perceive their line manager, personnel and career development specialist as being stimulating with regard to HRD activities and career development, and to what extent are they themselves mentally alert and willing to learn;

3. which HRD activities do older workers see as contributing to career development and to what extent are older employees' careers currently being developed?

The last sub-question gives an insight into the functioning of HRD specialists and the quality of their advice.

\section{Research design}

An exploratory survey was chosen because of the 'how-type' research question. To answer this, a questionnaire was developed and personally delivered to members of the target group. In total 312 middle-level employees (male and female), relatively highly-educated, working in different functions, received a questionnaire. Of these, 225 completed the questionnaire; a response rate of $72 \%$.

The questionnaire consisted of six groups of variables: existing HRD policy, the role of line managers, employees, the personnel department (as an 'umbrella' for mobility and HRD), career development specialists and HRD activities. The questionnaire was developed in three phases to ensure reliability and validity.

The statistical analysis began by investigating the non-response group. This showed that the non-response rates between sites were comparable; no systematic deviations were found. The analysis of the average age of the response and non-response group showed that it was the older workers who refused to cooperate. Nevertheless, the differences between the groups were very small (the response group was only 1.1 year younger, on average, than the population). We therefore concluded that the nature of the non-response had no serious consequences on interpreting the results.

The second step consisted of analysing the six groups of variables. A frequency analysis was performed by comparing the criterion for a sufficient condition, $60 \%$ agree, with actual scores. Then, an ANOVA-analysis was carried out to see whether there were differences between subgroups. For example, were there differences in perception between relatively younger and older employees? Finally, regression-analysis was carried out to search for relations between variables. The results of these last two steps are not shown here, because they are of particular in-company value.

\section{Results}

Only general trends are highlighted as it would go far beyond the purpose of this article to describe all the results in detail. 
Concerning the first research question of whether policy is directed to older workers; examination of the policy conditions revealed that the flexibility problems of older workers are recognised in policy statements. An explicit, written commitment within the company studied was to improve the working climate for older workers. However, according to the results, this strategic item has not yet resulted in taking real improvement action, so we may conclude that the management is still not optimally committed to the perceived problems of older workers. Personnel management is not embedded optimally into corporate strategy (only $47 \%$ of respondents partly or totally agree; see Table 1), while strategic, age-awareness choices are not yet fully communicated top-down through the organisation. The greatest obstacle for ageawareness personnel management is not a financial one; older workers believe management is willing to invest in career development education ( $90 \%$ of respondents partly or totally agree). However, in their opinion (73\%) HRD policy could be more sensitive to older workers' needs. Although older workers participate in HRD activities, this doesn't always meet their expectations. Personal career planning receives scant attention in educational policy $(18 \%$ of respondents partly or totally agree) and employees are too little informed about career interventions to anticipate adequately (14\% of respondents partly or totally agree).
With regard to the second research question, the roles of the various stakeholders and participants in the career development process, results show that line-managers are seen as the most stimulating and facilitating. Seeing that recent personnel management views show that human resources management tasks are delegated to line-managers, this is a positive point. Line-managers, however, are not optimally prepared and trained for their inspiring role $(44 \%$ of respondents think they are; see Table 2), but $86 \%$ of respondents indicated that line-managers had consulted their employees at least once in the past five years about career development and related educational needs, although these contacts declined among older employees. In most cases, however, line-managers perceived personnel development at all ages as important (64\% of respondents partly or totally agree). Line-managers and workers may also consult supporting specialists (personnel department and career development officers) for career advice, though these are generally perceived as not being particularly stimulating and supportive. Older workers felt that these officers were insufficiently open and accessible to them (Table 3 shows that $50 \%$ do not agree that these officers are open and accessible). Only $8 \%$ agree that these officers give adequate advice and show a special interest in their career development (see Table 3). It is possible that career development efforts concentrate on young high-potentials. Most

Table 1. A selection of the key responses to questions on policy

\begin{tabular}{|c|c|c|c|c|}
\hline & \multicolumn{4}{|c|}{ percentage respondents in any category } \\
\hline & $\begin{array}{l}\text { totally } \\
\text { agree }\end{array}$ & $\begin{array}{l}\text { partly } \\
\text { agree }\end{array}$ & $\begin{array}{c}\text { partly } \\
\text { disagree }\end{array}$ & $\begin{array}{c}\text { totally } \\
\text { disagree }\end{array}$ \\
\hline $\begin{array}{l}\text { 1. Personnel policy is embedded in } \\
\text { strategic policy }\end{array}$ & 6 & 41 & 35 & 16 \\
\hline $\begin{array}{l}\text { 2. The employer is willing to invest } \\
\text { in HRD activities that promote } \\
\text { career development }\end{array}$ & 43 & 47 & 6 & 0 \\
\hline $\begin{array}{l}\text { 3. HRD policy is sensitive to age- } \\
\text { related needs }\end{array}$ & 3 & 21 & 44 & 29 \\
\hline $\begin{array}{l}\text { 4. The employer teaches employees } \\
\text { the basic principles of personal } \\
\text { career planning }\end{array}$ & 2 & 16 & 30 & 51 \\
\hline $\begin{array}{l}\text { 5. Employees have sufficient } \\
\text { information on career } \\
\text { interventions }\end{array}$ & 2 & 12 & 30 & 54 \\
\hline
\end{tabular}


Table 2. A selection of key response rates to questions on line managers in the career development process

\begin{tabular}{|c|c|c|c|c|}
\hline & \multicolumn{4}{|c|}{ percentage respondents in a category } \\
\hline & $\begin{array}{l}\text { totally } \\
\text { agree }\end{array}$ & $\begin{array}{l}\text { partly } \\
\text { agree }\end{array}$ & $\begin{array}{l}\text { partly } \\
\text { disagree }\end{array}$ & $\begin{array}{l}\text { totally } \\
\text { disagree }\end{array}$ \\
\hline $\begin{array}{l}\text { 1. Line-managers are trained in their } \\
\text { stimulating role }\end{array}$ & 16 & 28 & 32 & 17 \\
\hline $\begin{array}{l}\text { 2. Line-managers perceive employee- } \\
\text { development at all ages as a } \\
\text { relevant task }\end{array}$ & 16 & 48 & 23 & 12 \\
\hline
\end{tabular}

Table 3. A selection of key response rates to questions on supporting specialists in career development

$\frac{\text { percentage respondents in any category }}{\text { agree neutral disagree }}$

The personnel department (PD)

1. PD is 'open' to/accessible for older workers $\quad 50 \quad 34$

2. PD gives adequate advice

$8 \quad 26 \quad 64$

Career development specialists (CDSs)

1. CDSs are 'open' to older workers

2. CDSs give adequate advice

$40 \quad 41 \quad 13$

$8 \quad 27 \quad 61$

respondents see themselves as active career development and HRD-activity entrepreneurs (see Table 4). For example, they are willing to learn (97\% partly or totally agree) and are capable of dealing with working activities outside their own narrowly defined function ( $90 \%$ partly or totally agree). The flipside is that they also confirm they have inadequate knowledge about personal career manage- ment (42\% partly or totally agree) and are badly coached, supported and stimulated by the organisation. The third research question concerns HRD activities and the extent to which careers are developed in the actual situation. To gain a picture of employees' attitude towards HRD activities, they were asked to rate the HRD activities they had attended over the previous five years.

Table 4. A selection of the key response rates to questions on employees' career development

1. Older workers are willing to learn new knowledge and skills

2. Older workers are capable of performing activities outside their own job function

3. Older workers have adequate personal career planning knowledge

percentage respondents in any category

\begin{tabular}{cccc}
\hline $\begin{array}{c}\text { totally } \\
\text { agree } \\
64\end{array}$ & $\begin{array}{c}\text { partly } \\
\text { agree }\end{array}$ & $\begin{array}{c}\text { partly } \\
\text { disagree }\end{array}$ & $\begin{array}{c}\text { totally } \\
\text { disagree }\end{array}$ \\
56 & 33 & 2 & 0 \\
9 & 34 & 5 & 3 \\
9 & 33 & 38 & 19 \\
& & & \\
\end{tabular}


Analysis showed that all employees had participated in at least one educational activity. Courses and training were the most frequent educational interventions $(85 \%$ of respondents had participated in a course or training during the 1990-1995 period; see Table 5). An important point is that HRD activities are not always effective in contributing to career development (49\% of respondents agree). Learning activities related to daily work activities, like job enrichment (71\% agree), temporary detachment (86\% agree) and working in multidisciplinary projects $(53 \%$ of respondents agree) are seen as being by far the most important in keeping older workers flexible and developing their careers. Taking the overall results, generally we can conclude that the conditions for career development are present. Important reasons for stating this are the fact that all employees are participating in HRD activities and their positive selfesteem in remaining flexible and multifunctional. But there are aspects which need improving, especially the supporting role of the organisation. These improvements are further outlined in the conclusion and discussion.

\section{Conclusion and discussion}

Here we have highlighted the major results of a survey on the existence of conditions supporting the career development of older employees in a multinational, chemical company, the role of the stakeholders in stimulating career development and the contribution

\section{Table 5. A selection of the key response rates to questions on HRD activities}

HRD-activities over the last five years and career development relevance

$$
\begin{array}{cc}
\% & \% \text { very } \\
\text { important }
\end{array}
$$

\begin{tabular}{lrr} 
1. Courses and & 85 & 49 \\
training & & \\
2. Job enrichment & 49 & 71 \\
$\begin{array}{l}\text { 3. Temporary } \\
\begin{array}{l}\text { detachments } \\
\text { Participation in }\end{array}\end{array}$ & 7 & 86 \\
\begin{tabular}{l} 
projects \\
\hline
\end{tabular} & & 53 \\
\hline
\end{tabular}

of HRD activities in older workers career development.

An initial conclusion is that the intention of having an age-awareness personnel policy is a good one, although daily practice does not always concur with this. Older workers feel insufficiently valued and treated in an age-awareness manner. Thus, there is a discrepancy between 'intended' and 'realised' policy. Major improvements to the organisational support can be achieved. Regarding the role of various stakeholders, it would be beneficial to (re)define and clarify their specific tasks and responsibilities. Line managers are perceived as being the most stimulating to career development, although they receive insufficient back-up by supporting specialists in specific situations. Personnel officers and career development specialists are held accountable for advising on career development, but according to workers fail in this task. It is particularly important to define clearly the position of these staff and equip them with the necessary instruments and skills to coach older workers. In the current situation the additional value of personnel specialists to line-managers is ambiguous. Although older workers are willing to learn and see themselves as capable employees, we may conclude that the organisation fails to tap their full potential. Their resulting negative feelings can create frustrations. Instead the organisation should apply these workers' rich work-experience and company-specific knowledge to realise strategic goals.

A second major conclusion relates to the organisation's attitude towards HRD activities. Frequently, HRD activities such as formal training and courses are seen as appropriate to meet the needs of older workers. This is a traditional viewpoint: people have to attend courses now and then, regardless of the value of the course and its appropriateness to personal needs. This attitude needs revising. Older workers need types of learning activities other than the formal ones. Development activities such as 'learning by doing', 'learning on the job' and 'individual coaching' are perceived as being far more relevant to career development. A good starting point is to make older workers feel important. One possible intervention is to create functions in which older workers can transfer their knowledge and experience to younger ones before they retire. Furthermore, in the composition of (project)teams, a mix of abilities 
and knowledge of both older and younger staff needs to be addressed.

A third conclusion concerns knowledge about personal career management. Since employees' responsibility for planning their careers is increasing, they need to be equipped with the relevant knowledge for this. This means the organisation has to provide the necessary information for planning careers, such as vacancies and possibilities for lateral moves, as well as develop personal career planning training, whereby skills are learned which prepare employees for the new responsibility of developing their own careers.

\section{References}

1. Alaerds, P. O., Kabinet hakt ouderenrichtlijn door; $\mathrm{P} \& \mathrm{O}$ moet meer armslag krijgen voor ouderenbeleid [The government does not allow the wholesale exit of older workers anymore; personnel departments need to get more freedom to search for possibilities to handle this new situation]. Personeelsbeleid, 30 (1), 1994, pp. 4-5; Heijden, van der, B. I. J. M., Mobiliteit ter bevordering van een bredere loopbaanontwikkeling [Mobility as supportive to a broader career perspective]. Opleiding en Ontwikkeling, 8 (7/8), 1995, pp. 25-30.

2. Boerlijst, G., Heijden, B. I. J.M. and van der Assen, A., Veertig-plussers in de onderneming [Older workers (40+) in organizations]. Assen/Maastricht, van Gorcum, 1993.

3. Kloet, van der H., Bijscholing houdt veertigplusser gemotiveerd [Education keeps older worker motivated]. PW-Vakblad voor personeelsmanagement, 11, 1994, pp.18-30; Boerlijst, Heijden and van der Assen, op. cit.

4. Zee, van der, H., Mobiliteitsbevordering: een vak in wording [Mobility stimulation: a new profession]. Opleiding \& Ontwikkeling, 1995, $8(7 / 8)$, pp. 5-6.

5. Paffen, M. J. A., Loopbaanmanagement [Career- management]. Deventer, Kluwer Bedrijfswetenschappen/NVP, 1991; Boerlijst, G., Heijden, B. I. J. M. and van der Assen, A., op. cit.

6. Daft, R. L., Organization Theory and Design. Saint Paul, West Publishing Company, 1992.

7. Beer, M. et al., Managing Human Assets. New York, The Free Press, 1984.

8. Caligiuri, P. M. and Stroh, L. K., Multinational corporation management strategies and international human resources practices: bringing IHRM to the bottom line. The International Journal of Human Resources Management, 1995, 6 (3), 494-504.

9. Rhebergen, B., Opleidingskundige condities die loopbaanontwikkeling van oudere medewerkers bevorderen [Educational conditions promoting career development of older workers]. Enschede, Universiteit Twente, 1995.

10. Hall, D. T. and Goodale, J. G., Human Resource Management: Strategy, design and implementation. Glenview, Illinois/London, Scott, Foresman and Company, 1986.

11. Paffen, M. J. A., op. cit.

12. Beer, M. et al., op. cit.

13. Ibid.

14. Boerlijst, G., Heijden, B. I. J. M. and van der Assen, A., op. cit.

15. Hall, D. T. and Goodale, J. G., op. cit.

16. Paffen, M. J. A., op. cit.

17. Begeer, H., Loopbaanontwikkeling in strategisch perspectief [Career development in strategical perspective]. MEO, tijdschrift voor organisatiekunde en sociaal beleid, 1990, 44:4, 381-395.

18. Hall, D. T. and Goodale, J. G., op. cit.

19. Boerlijst, G. et al., op. cit.; Paffen, M. J. A., op. cit.

20. Thijssen, J. G. L. and Prevoo, E. G. H. M., Bedrijfskundige condities voor scholingsdeelname in de midcareerfase [Organizational conditions to participation in educational activities in the mid-career]. In: Scholingsdeelname van oudere personeelsleden. Utrecht, Rabobank, 1994.

21. Boerlijst, G. et al. op. cit.; Hall, D. T. and Goodale, J. G. op. cit. 